\title{
LINKAGES BETWEEN PERSONALITY AND KNOWLEDGE SHARING BEHAVIOR IN WORKPLACE: MEDIATING ROLE OF AFFECTIVE STATES
}

\author{
Ch. Mahmood Anwar
}

\section{Introduction}

Knowledge is considered as a critical strategic resource for organizations in the contemporary knowledge-intensive economy. According to the resource based view of firms, one among other sources of firm's competitive advantage is knowledge. Research shows that knowledge sharing is a key enabler of knowledge management (Nonaka \& Takeuchi, 1995; Alavi \& Leidner, 2001). Many organizations assert knowledge sharing vital to exploit core competencies and to achieve sustained competitive advantage. Prahalad and Hamel (1990) observe that core competencies of organization reside in the collective learning of the organizational processes like marketing, production, or inimitable technological capabilities.

To investigate the factors influencing individuals to share knowledge, the role of big five personality dimensions, often known as extraversion, neuroticism, openness to experience, agreeableness and conscientiousness, is critical because "personality is an important determinant of individual behavior in the workplace" (Penney et al., 2011, p. 297). Despite studies suggesting that individuals are predisposed to certain work attitudes and behaviors (e.g., Judge and Bono (2001)), few studies have empirically tested the impact of individual personality on knowledge sharing. Wang and Noe (2010) identified in their review study exploring knowledge sharing behavior that only a few studies have objectively examined the influence of individual personality on knowledge sharing. Similarly, Jadin et al. (2013) affirm the importance of personality traits for knowledge sharing and highlight several caveats of their research.

It should be noted that extensively studied job attitudes such as job satisfaction (Judge \& Church, 2000), mainstream research has disregarded the affective facet of the concept and focused on the cogent and cognitive aspects (Judge \& Ilies, 2004). However, since the 1980s, organizational researchers emphasized that the emotional component must be explored in order to fully comprehend and explain organizational vivacity (Ashforth \& Humphrey, 1995). Keeping this in mind, inclusion of affect in our research schema is likely to contribute to the understanding of personality and knowledge sharing behavior. The literature shows that Weiss and Cropanzano's (1996) Affective Events Theory (AET) provides a valuable context to study the antecedents and consequences of emotions i.e. affective states in workplace.

It is obvious that the relationship between personality, emotions and knowledge sharing behavior is a topic of interest, as till the present year the enigma has not been solved yet (Jadin et al., 2013; Wang \& Noe, 2010). The present paper is an extension in the field of knowledge of personality, knowledge sharing and affective psychological dimensions in workplace. The purpose of this study is to contribute to theory and empirically test the relationship between personality and knowledge sharing behavior and any sacrifice offered by affective states between this relationship in workplace.

\section{Literature Review}

\subsection{Knowledge Sharing Behavior}

The nebulous nature of organizational knowledge makes it difficult to delineate it precisely (Nonaka \& Takeuchi, 1995). De Vries, Den Hooff and De Ridder (2006) describe knowledge sharing as a communication process between two or more persons. Whereas, Nonaka and Takeuchi (1995) view firm's knowledge as association between the organization and its environment followed by confirmed understanding and belief system. 
Organizations are setting knowledge sharing environment by promoting knowledge sharing behavior among their employees in order to achieve their goals and objectives. Many organizations found knowledge sharing strategies fruitful and beneficial (O'Dell \& Grayson, 1998). O'Dell and Grayson reported that companies such as Texas Instruments, Buckman Laboratories, Dow Chemical, and Chevron have been profited by implementing knowledge sharing process.

Cheng (2002) confirmed that, knowledge sharing can help workers to better understand their jobs, learn new dimensions to perform the job in effective and efficient ways, which can bring personal recognition within the division. Companies can achieve sustainable competitive advantage by processing existing knowledge and building new knowledge.

\subsection{Personality and Knowledge Sharing Behavior}

Awad and Ghaziri (2004) suggest that individual factor like personality influences knowledge sharing behavior. For instance, according to personality theory, extroverts are confident and feel secure which tend to share more knowledge with others as compared to introverts who are more self-centered and feel insecure.

Many studies suggest that people are predisposed to work attitudes and behaviors like the investigation taken by Judge and Bono (2001), but unfortunately, few studies investigated the relationship between personality and knowledge sharing behavior in workplace. Numerous factors have been identified which can affect the degree of knowledge sharing within groups and teams. On the individual level, personality traits can affect the knowledge sharing behavior in workplace (Matzler et al., 2008).

\section{Openness to Experience and Knowledge Sharing}

Research on five factor theory discloses that among big five facets, openness to experience is the most significant predictor of knowledge sharing behavior (Matzler \& Müller, 2011). Costa and McCrae (1988) report that open people always try to update their knowledge and learn from their new experiences. The same was reported by LePine and Van Dyne (2001). Wah (1999) describes that people high in openness to experience are intelligent and always willing to share their knowledge with others. These people believe in the increase of knowledge assets and intelligence which results from knowledge sharing to satisfy their thirst for knowledge. Based on these arguments, the following hypothesis is proposed:

Hypothesis 1: Openness to experience will positively predict knowledge sharing behavior in workplace.

\section{Conscientiousness and Knowledge Sharing}

Conscientiousness is realized as a noteworthy predictor of knowledge sharing (Matzler et al., 2008). Teh et al. (2011) studied link between personality and knowledge sharing in the university environment and found conscientious students' engagement in more knowledge sharing activities like sharing about their hobbies, favorite movies and music reviews.

People high in conscientiousness feel selfesteem in knowledge sharing (Hendriks, 1999). During the interaction, they reflect themselves as knowledge testimony. It has been observed that conscientiousness also affects learning behavior, which in turn influences knowledge sharing (Matzler \& Müller, 2011). This shows that erudition lustrous individuals, who think they can exhibit abilities, will be more inclined to share knowledge to execute that goal. Based on these theoretical arguments, the following hypothesis is proposed:

Hypothesis 2: Conscientiousness will positively predict knowledge sharing behavior in workplace.

\section{Extraversion and Knowledge Sharing}

Literature shows that extrovert people have positive emotions and feel satisfaction when working in groups and teams (McCrae \& Costa, 1987). So, these people might augment knowledge sharing among group members to increase the work efficiency. For instance, Gupta (2008) tested knowledge sharing behavior at university level and reported that fulfillment of group tasks of students rely on online resources available in library, extrovert students always try to share information with group members to furnish group assignments.

Knowledge sharing is actually based on knowledge exchange and correspondence. People high in extraversion tend to prove themselves as knowledge distributers. It is hypothesized that extraversion is also highly correlated to willingness to share knowledge. 
Ferguson et al. (2010) report a positive relationship between extroverts and knowledge sharing behavior; they share knowledge in their circles whether they would be rewarded or not (Wang et al., 2011). Based on these arguments the following hypothesis is proposed:

Hypothesis 3: Extraversion will positively predict knowledge sharing behavior in workplace.

\section{Agreeableness and Knowledge Sharing}

According to personality theory, agreeable people are naturally apt to help others, so inclined towards cooperation and collaboration with co-workers rather than competitiveness (Witt et al., 2002). Matzler et al. (2008) pen that parallel elements such as cooperation, collaboration, helpfulness, good interpersonal relationship at peer and superordinate level are essential dimensions for knowledge sharing as knowledge sharing itself is a form of individual helpfulness, cooperation and collaboration.

A person high in agreeableness trait may show willingness to exchange knowledge with others and in turn will share knowledge (De Vries et al., 2006). Agreeable persons are also high in trust and integrity which is related to knowledge sharing (Abrams et al., 2003).

According to Senge (1998) learning of people can be stimulated by knowledge sharing. Interaction between two persons is necessary for sharing knowledge. Szulanski (1996) argues that this interaction may lead to establish friendship for effective learning. At this point, $\mathrm{Wu}$ (2000) investigated that willingness to share knowledge is positively correlated to decent friendship. It is also highlighted by Cheng and Li (2001) that the degree of trust and integrity between individuals decides the level of knowledge sharing. People hide the detailed information if lack at trust in each other. Because agreeable people are trustworthy according to personality theory (Abrams et al., 2003), we may conclude that agreeableness will be positively correlated to knowledge sharing behavior. Based on these arguments, the following hypothesis is proposed:

Hypothesis 4: Agreeableness will positively predict knowledge sharing behavior in workplace.

\section{Neuroticism and Knowledge Sharing}

The role of trust is crucial in willingness to share knowledge as argued by Cheng and $\mathrm{Li}$ (2001). Because neurotic people reflect anxiety, fear and mistrust, this impacts the knowledge sharing behavior negatively. The trepidation and angst based on the fear of negative assessment by others, neurotic people dither to share their knowledge and ideas with colleagues (Bordia et al., 2006). Research shows that trust and integrity is related to knowledge sharing behavior (Abrams et al., 2003), whereas neurotic people lack at trust in people, which leads to a negative relationship between neuroticism and knowledge sharing behavior. In difference, Wang and Yang (2007) did not find a statistically significant association between knowledge sharing intention and neuroticism. Based on these arguments and theoretical support, the following hypothesis is proposed:

Hypothesis 5: Neuroticism will negatively predict knowledge sharing behavior in workplace.

\subsection{Narrow Personality Traits}

Many scholars highlighted the need to investigate specific facets of human behavior which are smaller in scope than big five dimensions. For example, John and Srivastava (1999) report that wide agreeableness dimension consists of narrow facets such as tender mindedness, trust, truism and modesty. Many narrow traits may or may not be related to famous big five personality traits. Many studies exploring narrow traits have added and explained the variance beyond the big five model as reported by Logue et al. (2007).

Based on these facts and significance of narrow personality facets reflected in literature, it was decided to include two narrow traits (i.e. proactive personality and creative self-efficacy) in this study.

\subsection{Proactive Personality and Knowledge Sharing}

Generally, proactive personality can be defined as "a dispositional tendency to take initiatives across a range of situations and activities by an individual" (Crant, 2000). Direct evidence about the relationship between proactive personality and knowledge sharing behavior is rare in literature because proactive personality is relatively new and less explored construct as compared to other personality traits. In a PriceWaterhouse conducted study, Coopers uncovered that a strong proactive, outgoing personality is important for knowledge sharing 
and is more important than qualifications and previous experience of an individual (Webb, 1998). Similarly, Belschak et al. (2010) report that proactive individuals take initiative to share their knowledge. According to Major et al. (2006), proactive individuals are fervent to learn new things and found to be engaged in activities essential to ripen their knowledge and skills. Proactivity theory literature (e.g., Crant, 2000) discusses three antecedents, in which individual difference is important to our present study. These individual differences consider the knowledge, skills, abilities and dispositional factors. Based on these arguments the following hypothesis is proposed:

Hypothesis 6: Proactive personality will positively predict knowledge sharing behavior in workplace.

\section{Creative Self-Efficacy and Knowledge Sharing}

Tierney and Farmer (2002) define creative self-efficacy as "the belief one has the ability to produce creative outcomes". Creative selfefficacy is relatively a new construct, so direct evidence of association between creative selfefficacy and knowledge sharing behavior is limited in literature. However, literature supports the association between knowledge sharing, creativity and self-efficacy.

According to Sternberg and Lubart (1999), knowledge is essential for creativity, whether it be formal or informal. Knowledge provides the bases for logical reasoning. This suggests that learning processes, organizational performance, effective decision making and problem solving, innovation and creativity all require new knowledge. Tierney and Farmer (2002) identify that people high in creative self-efficacy are found to be engaged in knowledge and information searching and sharing activities. A study exploring the effects of training on creativity related self-efficacy conducted by Locke et al. (1984) concludes, that training of employees aggrandize their cognitive processes and creative thinking which results in incremental change of creativity related self-efficacy. Similarly, Gist (1989) confirms that creativity interventions like lecturing, brainstorming sessions and cognitive modeling affect creative self-efficacy positively. It can be seen that all these interventions are based on effective knowledge sharing process. Based on these arguments the following hypothesis is proposed:
Hypothesis 7: Creative self-efficacy will positively predict knowledge sharing behavior in workplace.

\subsection{Theoratical Framework for Mediation}

After a deep research on 'Cognitive Judgement Approach', 'Social Influence Approach' and 'Dispositional Approach' as grounding theories for job satisfaction and other theoretical signposts indicating affective reactions, Weiss and Cropanzano (1996) established their position as Affective Events Theory (AET) and differentiated it from traditional theories by focusing on the structure, causes and consequences of affective experiences in workplace. According to the theory, the events occur in workplace are nigh causes of affective reactions by the workers. People react to these events emotionally; these experiences have a direct effect on attitudes and behaviors of people. AET explores the nature of these effects as affective events are the result of environmental features that influence affects primarily.

Previous theories suggest that work environment features predict work attitudes but AET argues that in addition to this, some features also generate work events and the affective reactions leading to certain work attitudes and behaviors. However, AET does not ignore the dispositional influences on work events and affective reactions. These affective reactions produce work attitudes and behaviors, now it is clear that the consequences of affective experiences are attitudinal and behavioral as well. The outcomes of these attitudes are behaviors and behaviors have two categories: affect driven and judgment driven. Affect driven behaviors are direct outcome of affective experiences and have no effect of sacrifice offered by overall attitudes. However, these behaviors are influenced by mood management, coping, cognitive processing or judgment biases. Whereas, judgment driven behaviors are sacrificed by attitudes such as satisfaction, these behaviors are the consequences of decision processes. In the present study, I consider knowledge sharing behavior as an affect driven behavior. AET argues that emotion itself is a reaction to an event and not a trait, but chronic affect levels may change with trait differences. 


\subsection{Affects, Knowledge Sharing and Personality}

Literature provides evidence that the role of affects in knowledge processing, creative thinking, group efficiency, negotiations and trust is critical, and unobserved (Kopelman et al., 2006). No doubt, scholars explored the domain of knowledge exchange in terms of various cognitive impediment constructs but the absence of affective dimension can easily be observed in the literature of knowledge sharing and information transfer (Levin et al., 2010).

Personality literature indicates that extroverts have a tendency to feel positive emotions and in contrast neurotics are inclined towards negative aspects of life and reflect negative emotions (Kokkonen \& Pulkkinen, 2001a). Literature reflects strong association of extraversion and neuroticism with emotions but Tobin et al. (2000) and Haas et al. (2007) also associate agreeableness to emotional reactions and regulation in their studies. Panaccio and Vandenberghe (2012) provide strong evidence that agreeableness and extraversion are predisposed towards positive affective state and neuroticism towards negative affective state. As far as creative self-efficacy is considered, studies like Bandura and Cervone (1983), Mone and Baker (1992), and Thomas and Mathieu (1994) reported the evidence about the negative relationship of self-efficacy and negative affect. Based on these arguments, the following hypotheses are proposed:

Hypothesis 8: Positive affect offers a mediational effect between the relationship of extraversion and knowledge sharing behavior.

Hypothesis 9: Positive affect offers a mediational effect between the relationship of agreeableness and knowledge sharing behavior.

Hypothesis 10: Negative affect offers a mediational effect between the relationship of neuroticism and knowledge sharing behavior.

Hypothesis 11: Positive affect offers a mediational effect between the relationship of creative self-efficacy and knowledge sharing behavior.

\section{Methodology}

\subsection{Sample and Procedure}

The standard surveys were distributed to 341 volunteer study subjects along with a brief description of study and invitation to participate in this study. The simple random sampling without replacement (SRSWOR) technique was used in present study. The assessment of population was made through statistics reported in Pakistan Education Statistics 2010-2011 prepared by Academy of Educational Planning and Management (AEPAM), Islamabad. From sampling frame of 3,000 elements (university teachers of Pakistan), sample size of 341 subjects was determined by using Krejcie and Morgan (1970) table for sample size determination. The questionnaires were designed by using Google Drive technology and disseminated to the subjects of study through email at time 1 and time 2 (after 8 weeks). The language of questionnaires was English because it is official language of Pakistan. Out of 341 questionnaires, 293 were received back (response rate $=85.92 \%$ ). After initial analysis and assiduously checking all surveys for errors, accuracy of data and missing values, it was found that 17 time 1 questionnaires and 25 time 2 questionnaires were not usable. Hence, 274 (93.51\% of received responses) responses were finally selected after resolving few conflicts of responses due to different time points and recovering the missing values by mean substitution in our response matrix. The demographics of the sample are shown in Tab. 1.

\subsection{Instruments Measures for Time I}

Big Five Personality Dimensions. The personality of employees was measured by using well known "Big Five Inventory (BFI)" cited by John and Srivastava (1999). The BFI measures five broad personality dimensions with 44, 5-point Likert items. Internal consistencies (alpha coefficient) obtained in the current study were .83 for openness to experience, .77 for conscientiousness, .74 for extraversion, .79 for agreeableness, and .74 for neuroticism.

Proactive Personality. Proactive personality was tapped with 10-items, 7-point Likert scale developed by Seibert, Crant and Kraimer (1999). Example items are, "Nothing is more exciting than seeing my ideas turn into reality" and "I excel at identifying opportunities" $(\alpha=.90)$.

Creative Self-Efficacy. 3-items, 7-point Likert scale developed by Tierney and Farmer's (2002) to measure creative self-efficacy was used in present study. Sample items of scale are "I feel that I am good at generating novel 


\section{Tab. 1: Descriptive Statistics $(n=274)$}

\begin{tabular}{|c|c|c|c|}
\hline Variable & & $\mathbf{n}$ & $\%$ \\
\hline \multicolumn{4}{|l|}{ Gender } \\
\hline & Male & 215 & 78.47 \\
\hline & Female & 59 & 21.53 \\
\hline \multicolumn{4}{|l|}{ Age } \\
\hline & $20-29$ & 27 & 9.85 \\
\hline & $30-39$ & 59 & 21.53 \\
\hline & $40-49$ & 56 & 20.43 \\
\hline & $50-59$ & 89 & 32.48 \\
\hline & $60-69$ & 43 & 15.69 \\
\hline \multicolumn{4}{|l|}{ Education } \\
\hline & Bachelor's Degree & 42 & 15.32 \\
\hline & Graduate Degree & 116 & 42.33 \\
\hline & Post Graduate Degree & 116 & 42.33 \\
\hline
\end{tabular}

\section{Tab. 2: Correlation Matrix $(p<.01)$}

\begin{tabular}{c|l|r|r|r|r|r|r|r|r|c}
\multicolumn{1}{|c|}{ Variables } & $\mathbf{1}$ & $\mathbf{2}$ & $\mathbf{3}$ & $\mathbf{4}$ & $\mathbf{5}$ & $\mathbf{6}$ & $\mathbf{7}$ & $\mathbf{8}$ & $\mathbf{9}$ \\
\hline 1. & Openness & & & & & & & & & \\
\hline 2. & Conscientiousness & .34 & & & & & & & & \\
\hline 3. & Extraversion & .19 & .27 & & & & & & & \\
\hline 4. & Agreeableness & .41 & .21 & .15 & & & & & & \\
\hline 5. & Neuroticism & -.36 & -.47 & -.34 & -.33 & & & & & \\
\hline 6. & Proactive Personality & .34 & .11 & .27 & .33 & -.46 & & & & \\
\hline 7. & Creative Self-Efficacy & .29 & .16 & .57 & .43 & -.41 & .59 & & & \\
\hline 8. & PA & .25 & .19 & .32 & .16 &.-34 & .22 & .36 & & \\
\hline 9. & NA & -.21 & -.15 & -.29 & -.21 & .37 & -.26 & -.18 & -.49 & \\
\hline 10. & Knowledge Sharing Behavior & .24 & .19 & .41 & .29 & -.43 & .53 & .49 & .33 & -.29 \\
\hline
\end{tabular}

Source: own research analysis

ideas" and "I have a knack for further developing the ideas of others" ( $\alpha=.83)$.

\section{Measures for Time II}

Knowledge Sharing Behavior. Knowledge sharing behavior was assessed by using 7-items, 7-point Likert scale as suggested by Chennamaneni (2006). The sample items are "I shared factual knowledge (know-what) from work with my co-workers" and "I shared work experiences with my co-workers" $(\alpha=.91)$.
Affective States. Positive and Negative affective states (PA/NA) of the employees were assessed by using 20-items, 5-point, Positive and Negative Affect Schedule (PANAS) developed by Watson, Clark and Tellegan (1988). Sample items for PANAS scale are "interested" and "Inspired" ( $\alpha=.85)$ for positive affective state and "ashamed" and "afraid" $(\alpha=.84)$ for negative affective state. 


\section{Results}

\subsection{Correlation Analysis}

The correlation between independent variables and dependent variable can be seen in Tab. 2 . The bivariate relationships shown in the correlation matrix indicate interim support to hypotheses 1-7 dealing with broad personality traits, narrow personality traits and knowledge sharing behavior.

\subsection{Regression Analysis}

The sequential regression analysis was executed to test hypotheses. In the first step, age, education and gender (control variables) and knowledge sharing behavior (dependent variable) were entered and then big five broad personality traits i.e. neuroticism, extroversion, openness, agreeableness and conscientiousness were entered to the model in second step, after that narrow personality traits i.e. proactive personality and creative selfefficacy were entered to the model in third step.

The results of the sequential regression analysis presented in Tab. 3 indicate that neuroticism $(\beta=-.34, p<.001)$, extroversion $(\beta=.25, p<.001)$, openness $(\beta=.21$, $p<.001)$, agreeableness $(\beta=.14, p<.01)$ conscientiousness $(\beta=.12, p<.01)$, proactive personality $(\beta=.49, p<.001)$ and creative self-efficacy $(\beta=.27, p<.001)$ are significant predictors of knowledge sharing behavior, hence the findings provided well support to hypotheses 1-7. Besides that, total estimated variance explained by the model was 40 percent, with the broad traits block explaining 28 percent of the variance. It can be seen that addition of narrow traits significantly explained 12 percent of variance beyond the broad traits.

\subsection{Mediation Analysis}

The mediation effects were analyzed (see Tab. 4) by using bootstrapping method as suggested by Preacher and Hayes (2008). To test the indirect effects as proposed in hypothesis 8 to hypothesis $11,5,000$ bootstrap resampling with bias corrected and accelerated design was applied including a 95 percent confidence interval.

For hypothesis 8 the true effects of positive affect were estimated to lay between .3167 and .4801. Because zero is not in the 95 percent confidence interval for positive affect, it can be concluded that the mediation effect is significantly different from zero at $p<.05$, and that positive affect partially mediates the

\section{Tab. 3: Results of Regression Analyses for Knowledge Sharing Behavior}

\begin{tabular}{|c|c|c|c|}
\hline \multirow[b]{2}{*}{ Predictors } & \multicolumn{3}{|c|}{ Knowledge Sharing Beh. } \\
\hline & $\beta$ & $R^{2}$ & $\Delta R^{2}$ \\
\hline \multicolumn{4}{|l|}{ Personality types } \\
\hline \multicolumn{4}{|l|}{ Step 1} \\
\hline Control variables & & .01 & \\
\hline \multicolumn{4}{|l|}{ Step 2} \\
\hline Neuroticism & $-.34^{* *}$ & & \\
\hline Agreeableness & $.14^{*}$ & & \\
\hline Extroversion & $.25^{\star *}$ & & \\
\hline Openness & $.21^{* \star}$ & & \\
\hline Conscientiousness & $.12^{*}$ & .29 & $.28^{\star \star}$ \\
\hline \multicolumn{4}{|l|}{ Step 3} \\
\hline Proactive personality & $.49^{\star *}$ & & \\
\hline Creative self-efficacy & $.27^{\star *}$ & .41 & $.12^{\star \star}$ \\
\hline
\end{tabular}

Note: $n=274$; control variables were age, education and gender

* $p<.01$

${ }_{* *}^{*} p<.001$ 
Tab. 4: Results of Bootstrapping Mediation

\begin{tabular}{l|c|c|c|c|c|c}
\multicolumn{1}{c|}{ IV } & MV & $\begin{array}{c}\text { Effect of IV } \\
\text { on MV }\end{array}$ & $\begin{array}{c}\text { Effect of } \\
\text { MV on DV }\end{array}$ & $\begin{array}{c}\text { Direct } \\
\text { effects }\end{array}$ & $\begin{array}{c}\text { Indirect } \\
\text { effect }\end{array}$ & $\begin{array}{c}\text { Total } \\
\text { effects }\end{array}$ \\
\hline Extraversion & $\begin{array}{c}\text { Positive } \\
\text { Affect }\end{array}$ & $.5965^{* *}$ & $.4708^{* *}$ & $.2306^{* *}$ & $.2976^{*}$ & $.5282^{* *}$ \\
\hline Agreeableness & $\begin{array}{c}\text { Positive } \\
\text { Affect }\end{array}$ & $.4338^{* *}$ & $.3362^{* *}$ & $.2555^{* *}$ & $.2032^{*}$ & $.4588^{* *}$ \\
\hline Neuroticism & $\begin{array}{c}\text { Negative } \\
\text { Affect }\end{array}$ & $.4615^{* *}$ & $-.3475^{* *}$ & $-.3456^{* *}$ & $-.2169^{*}$ & $-.5625^{* *}$ \\
\hline $\begin{array}{l}\text { Creative Self } \\
\text { Efficacy }\end{array}$ & $\begin{array}{c}\text { Positive } \\
\text { Affect }\end{array}$ & $.6178^{* *}$ & $.5738^{* *}$ & $.3581^{* *}$ & $.3545^{*}$ & $.7126^{* *}$ \\
\hline
\end{tabular}

Source: own

Note: DV, dependent variable; MV, mediating variable; IV, independent variable.

*Significant point estimate $(p<.05)$

${ }^{* *} p<.0001$

relationship between extraversion and knowledge sharing behavior.

For hypothesis 9 the true effects of positive affect were estimated to lay between .3274 and .4855. Because zero is not in the 95 percent confidence interval for positive affect, we can conclude that the indirect effect is significantly different from zero at $p<.05$, and that positive affect partially mediates the relationship between agreeableness and knowledge sharing behavior.

The true effects of negative affect were estimated to lay between -.5131 and -.3232 for hypothesis 10 . Because zero is not in the 95 percent confidence interval for negative affect, we can conclude that the indirect effect is significantly different from zero at $p<.05$, and that negative affect partially mediates the relationship between neuroticism and knowledge sharing behavior.

The outcome of analysis to test hypothesis 11 showed that the true effects of positive affect were estimated to lay between .2855 and .4306. Because zero is not in the 95 percent confidence interval for positive affect, we can conclude that the indirect effect is significantly different from zero at $p<.05$, and that positive affect partially mediates the relationship between creative self-efficacy and knowledge sharing behavior.

\section{Discussion}

The first hypothesis of this study states that openness to experience will positively predict knowledge sharing behavior in workplace. The results of this study support the hypothesis as correlation and regression analysis reflect a strong positive relationship between openness to experience and knowledge sharing behavior supporting the results of Cabrera et al. (2006) and Wang and Yang (2007).

Second hypothesis of this study ascribes that conscientiousness will positively predict knowledge sharing behavior in workplace. The literature also provides the similar findings as our results are in line with that of Teh et al. (2011), LePine and Van Dyne's (2001) and Matzler and Müller (2011).

The third hypothesis asserts that extraversion will positively predict knowledge sharing behavior in workplace. The results of this study reflect positive association between extraversion and knowledge sharing behavior. This is because people with this personality type are sociable, energetic, enthusiastic, talkative, and need recognition and power. People with this personality expose dominance and affiliation (Costa \& McCrae, 1988; Robbins et al., 2008). Extraversion is marked as being sociable and enjoying cooperation with people (Mount et al., 1998). This social networking ability and will of recognition and power compel the extroverts to exchange their knowledge in their networks, groups and teams.

Fourth hypothesis states that agreeableness will positively predict knowledge sharing behavior in workplace. The results show positive relationship between agreeableness and knowledge sharing behavior. This is because people high in this trait are trustworthy 
and exhibit integrity according to Abrams et al. (2003), this makes others to ask questions to agreeable people and in return they exchange their knowledge with other people.

Fifth hypothesis states that neuroticism will negatively predict knowledge sharing behavior in workplace. Results indicate that this trait has negative relationship with knowledge sharing behavior. This is because the trepidation and angst based on the fear of negative assessment by others, neurotic people dither to share their knowledge and ideas with peers. The same was reported by Bordia et al. (2006) and, Cheng and $\mathrm{Li}$ (2001) that neurotic people reflect anxiety, fear and mistrust which impacts the knowledge sharing negatively.

The sixth hypothesis states that proactive personality will positively predict knowledge sharing behavior in workplace. The results show positive correlation between proactive personality and knowledge sharing behavior. According to Coopers, strong proactive, outgoing personality is important for knowledge sharing and is more important than qualifications and previous experience of an individual (Webb, 1998).

The seventh hypothesis states that creative self-efficacy will positively predict knowledge sharing behavior in workplace. The correlation and regression show positive relationship between creative self-efficacy and knowledge sharing behavior. The results are in line with Tierney and Farmer (2002) as they found high engagement of people high in creative self-efficacy in knowledge and information searching and sharing activities.

According to the eighth hypothesis, positive affect offers a mediating effect between extraversion and knowledge sharing behavior. The bootstrap mediation result shows that the relationship between extraversion and knowledge sharing behavior is partially mediated by positive affect. The result is in line as discussed in literature review because personality literature indicates that extroverts have a tendency to reflect positive emotions and in contrast neurotics are inclined towards negative aspects of life and reflect negative emotions (Kokkonen \& Pulkkinen, 2001a; $2001 \mathrm{~b}$ ), which is evident from the result of tenth hypothesis showing that the association between neuroticism and knowledge sharing behavior is partially mediated by negative affect.
The results of ninth and eleventh hypotheses show that the relationship of agreeableness and creative self-efficacy with knowledge sharing behavior is partially mediated by positive affect. Literature reflects strong association of extraversion and neuroticism with emotions but Tobin et al. (2000) and, Haas et al. (2007) also associate agreeableness to emotional reactions and regulation in their studies. As far as creative self-efficacy is considered, studies like Bandura and Cervone (1983), Mone and Baker (1992) and Thomas and Mathieu (1994) reported the evidence about the negative relationship of self-efficacy and negative affect. Hence, it can be seen that the results of this study significantly contribute to literature and satisfy the research found in previous literature.

\section{Conclusion}

Based on the results of this study, it can be concluded that both broad and narrow personality traits are important to achieve organizational success through promoting knowledge sharing behavior in organizations. Managers and employees should be trained to effectively handle affective reactions caused by affective events in workplace. It is now clear that both positive and negative affects mediate the relationship between personality and knowledge sharing behavior. Hence, this study establishes the fact that affects play an important role to transfer the effects of personality types to knowledge sharing behavior in workplace. In other words, affects intervene between personality and knowledge share behavior.

This study highlights the importance of knowledge based capital (human) and their emotions to achieve sustainable competitive advantage. Like job-personality relationship, managers should also keep in mind that work events cause the affective reactions and these reactions in turn influence the knowledge sharing behavior of human capital. Neglecting emotional effects, they may lose the competitive advantage achieved through knowledge based human assets. Managers should understand that success cannot be achieved without creating a knowledge sharing environment; hence, they should assign all works and jobs requiring knowledge sharing and training of employees to those persons having high levels of knowledge sharing supporting personality types. 
I suggest that organizations could adopt personality test (for broad and narrow personality types) as a standard practice in hiring new employees. This will help managers in task assignment to staff as every member of staff should be given tasks according to theirpersonality type. All the sophisticated, technical and scientific works requiring high level of knowledge sharing should not be assigned to neurotic employees. However, extrovert, agreeable, conscientious, and open individuals may handle all knowledge sharing activities effectively. It is also suggested that the works requiring scientific innovation and creativity could better be performed by people high in creative self-efficacy, whereas, knowledge works requiring manual dexterity like technology transfer, industry academia linkages and knowledge based networking can best be done by proactive people. Members of organizations, at all levels, should be trained to manage their emotions and affective reactions intelligently. This training will also help the managers and staff to get better psychological insights of each other and hence many interpersonal and work related conflicts will be weeded out.

Like every scholarly research, this research also has few limitations. I have included only two relatively high level narrow personality traits in the model, other low level narrow personality traits must be tested to find the effects on knowledge sharing behavior. As far as methodology is concerned, I limit the random element selection up to three shots of the sampling frame, which could be enhanced to increase the chances of selection of elements for the final analyses. It should also be noted that I limit my sampling frame to a specific high level knowledge sharing segment of the society (university teachers), other segments or sectors like banking, government organizations and scientific industries or their combination could be included in the research and multiple sampling frames can be formed to strengthen and generalize the findings. Future studies should also explore the interceding effects of positive and negative affects on the relationship of remaining personality types.

\section{References}

Abrams, L. C., Cross, R., Lesser, E., \& Levin, D. Z. (2003). Nurturing interpersonal trust in knowledge sharing networks. Academy of Management Executives, 17(4), 64-77. doi:10.5465/AME.2003.11851845.
Alavi, M., \& Leidner, D. E. (2001). Knowledge management and knowledge management systems: Conceptual foundations and research issues. MIS Quarterly, 25(1), 107-136. doi:10.2307/3250961.

Ashforth, B. E., \& Humprey, R. H. (1995). Emotion in the workplace: A reappraisal. Human Relations, 48(2), 97-125. doi:10.1177/001872679504800201.

Awad, E. M., \& Ghaziri, H. M. (2004). Knowledge management. Upper Saddle River, $\mathrm{NJ}$ : Pearson Education Inc.

Bandura, A., \& Cervone, D. (1983). Selfevaluative and self-efficacy mechanisms governing the motivational effects of goal systems. Journal of Personality and Social Psychology, 45(5), 1017-1028.

Barrick, M. R., \& Mount, M. K. (1991). The big five personality dimensions and job performance: A meta-analysis. Personnel Psychology, 44(1), 1-26. doi:10.1111/j.1744-6570.2003.tb00143.

Belschak, F. D., Hartog, D. N., \& Fay, D. (2010). Exploring positive, negative and context-dependent aspects of proactive behaviors at work. Journal of Occupational and Organizational Psychology, 83(2), 267-273. doi:10.1348/096317910X501143.

Bordia, P., Irmer, B. E., \& Abusah, D. (2006). Differences in sharing knowledge interpersonally and via databases: The role of evaluation apprehension and perceived benefits. European Journal of Work and Organizational Psychology, 15(3), 262-280. doi:10.1080/13594320500417784.

Cabrera, A., Collins, W. C., \& Salgado, J. F. (2006). Determinants of individual engagement in knowledge sharing. International Journal of Human Resource Management, 17(2), 245-264. doi:10.1080/09585190500404614.

Chennamaneni, A. (2006). Determinants of knowledge sharing behavior: Developing and testing an integrated theoretical model (Doctoral dissertation). Faculty of Graduate School, University of Texas.

Cheng, J. W., \& Li, S. C. (2001). The Relationships of Organization Justice, Trust and Knowledge Sharing Behaviors. Journal of Human Resource Management, 1(2), 69-93.

Cheng, M. Y. (2002). Socializing knowledge management: The influence of the opinion leader. Journal of Knowledge Management Practice, 3. Available from http://www.tlainc.com/articl42.htm.

Costa, P. T., Jr., \& McCrae, R. R. (1988). From catalog to classification: Murray's needs 
and the five-factor model. Journal of Personality and Social Psychology, 55(2), 258-265. doi:10.1037/0022-3514.55.2.258.

Crant, M. J. (1996). The proactive personality scale as a predictor of entrepreneurial intentions. Journal of Small Business Management, 34(3), 42-49.

Crant, M. J. (2000). Proactive behavior in organizations. Journal of Management, 26(3), 435-462. doi:10.1177/014920630002600304.

De Vries, R. E., Den Hooff, B. V., \& De Ridder, J. A. (2006). Explaining knowledge sharing: The role of team communication styles, job satisfaction and performance beliefs. Communication Research, 33(2), 115-135. doi:10.1177/0093650205285366.

Ferguson, R. J., Paulin, M., \& Bergeron, J. (2010). Customer sociability and the total service experience: antecedents of positive word-of-mouth intentions. Journal of Service Management, 20(1), 25-44. doi:10.1108/09564231011025100.

Gist, M. E. (1989). The influence of training method on self-efficacy and idea generation among managers. Personnel Psychology, 42(2), 787-805. doi:10.1111/j.1744-6570.1989.tb00675.x.

Gupta, B. (2008). Role of personality in knowledge sharing and knowledge acquisition behavior. Journal of the Indian Academy of Applied Psychology, 34(1), 143-149.

Haas, B. W., Omura, K., Constable, R. T., \& Canli, T. (2007). Is automatic emotion regulation associated with agreeableness? A perspective using a social neuroscience approach. Psychological Science, 18(2), 130132. doi:10.1111/j.1467-9280.2007.01861.x.

Hendriks, P. H. J. (1999). Why share knowledge? The influence of ICT on the motivation for knowledge sharing. Knowledge and Process Management, 6(2), 91-100. doi:10.1002/ (SICl)1099-1441(199906)6:23.0.CO;2-M.

Jadin, T., Gnambs, T., \& Batinic, B. (2013). Personality traits and knowledge sharing in online communities. Computers in Human Behavior, 29(1), 210-216. doi:10.1016/j. chb.2012.08.007.

John, O. P., \& Srivastava, S. (1999). The Big-Five trait taxonomy: History, measurement, and theoretical perspectives. In L. A. Pervin \& O. P. John (Eds.), Handbook of personality: Theory and research (Vol. 2, pp. 102-138). New York: Guilford Press.

Judge, T. A., \& Church, A. H. (2000). Job satisfaction: Research and practice. In C. L.
Cooper \& E. A. Locke (Eds.), Industrial and organizational psychology: Linking theory with practice (pp. 166-198). Oxford, UK: Blackwell.

Judge, T. A., \& Bono, J. E. (2001). Relationship of Core self-evaluations traitsselfesteem. generalized self-efficacy, locus of control, and emotional stability-with job satisfaction and job perfonnance: A metaanalysis. Journal of Applied Psychology, 86(1), 80-92.

Judge, T. A., \& Ilies, R. (2004). Affect and job satisfaction: A study of their relationship at work and at home. Journal of Applied Psychology, 89(4), 661-673. doi:10.1037/00219010.89.4.661.

Kopelman, S., Rosette, A., \& Thompson, L. (2006). The three faces of Eve: Strategic displays of positive neutral and negative emotions in negotiations. Organizational Behavior and Human Decision Processes, 99(1), 81-101. doi:10.1016/j.obhdp.2005.08.003.

Kokkonen, M., \& Pulkkinen, L. (2001a). Examination of the paths between personality, current mood, its evaluation, and emotion regulation. European Journal of Personality, 15(2), 83-104. doi:10.1002/per.397.

Kokkonen, M., \& Pulkkinen, L. (2001b). Extraversion and neuroticism as antecedents of emotion regulation and dysregulation in adulthood. European Journal of Personality, 15(6), 407-424. doi:10.1002/per.425.

Krejcie, R. V., \& Morgan, D. W. (1970). Determining sample size for research activities. Educational and Psychological Measurement, 30(3), 607-610.

Lee, J. (2001). The impact of knowledge sharing, organizational capability and partnership quality on IS outsourcing success. Information and Management, 38(5), 323-335. doi:10.1016/S0378-7206(00)00074-4.

LePine, J. A., \& Dyne, L. V. (2001). Voice and cooperative behavior as contrasting forms of contextual performance: Evidence of differential relationships with big five personality characteristics and cognitive ability. Journal of Applied Psychology, 86(2), 326-336.

Levin, D. Z., Kurtzberg, T., Phillips, K. W., \& Lount, R. B., Jr. (2010). The role of affect in knowledge transfer. Group Dynamics, 14(2), 123-142. doi:10.1037/a0017317.

Logue, C. T., Lounsbury, J. W., Gupta, A., \& Leong, F. T. L. (2007) Vocational interest themes and personality traits in relation to college major satisfaction of business students. 
Journal of Career Development, 33(3), 269-295. doi:10.1177/0894845306297348.

Locke, E. A., Frederick, E., Lee, C., \& Bobko, P. (1984). The effect of self-efficacy, goals, and task strategies on task performance. Journal of Applied Psychology, 69(2), 241-252.

Matzler, K., Renzi, B., Muller, J., Herting, S., \& Mooradian, T. A. (2008). Personality Traits and Knowledge Sharing. Journal of Economic Psychology, 29(3), 301-313. doi:10.1016/j.joep.2007.06.004.

Matzler, K., \& Müller, J. (2011). Antecedents of knowledge sharing - Examining the influence of learning and performance orientation. Journal of Economic Psychology, 32(3), 317-329. doi:10.1016/j.joep.2010.12.006.

Major, D. A., Turner, J. E., \& Fletcher, T. D. (2006). Linking proactive personality and the Big Five to motivation to learn and development activity. Journal of Applied Psychology, 91(4), 927-935. doi:10.1037/0021-9010.91.4.927.

McCrae, R. R., \& Costa, P. T., Jr. (1987). Validation of the five-factormodel of personality across instruments and observers. Journal of Personality and Social Psychology, 52(1), 81-90.

Mone, M.A., \& Baker, D.D. (1992). Cognitive, affective, and behavioral determinants and consequences of self-set goals: An integrative, dynamic model. Human Performance, 5(3), 213-234. doi:10.1207/s15327043hup0503_3.

Mount, M. K., Barrick, M. R., \& Stewart, G. L. (1998). Five-factor model of personality and performance in jobs involving interpersonal interactions. Human Performance, 11(2-3), 145-165. doi:10.1207/s15327043hup1102\&3_3.

Nonaka, I., \& Takeuchi, H. (1995). The knowledge creating company: How Japanese companies create the dynamics of innovation. New York: Oxford University Press.

O'Dell, C., \& Grayson, J. C. (1998). If only we knew what we know: The transfer of internal knowledge and best practice. New York: The Free Press.

Panaccio, A., \& Vandenberghe, C. (2012). Five-factor model of personality and organizational commitment: The mediating role of positive and negative affective states. Journal of Vocational Behavior, 80(3), 647-658. doi:10.1016/j.jvb.2012.03.002.

Penney, L. M., David, E., \& Witt, L. A. (2011). A review of personality and performance: Identifying boundaries, contingencies, and future research directions. Human Resource
Management Review, 21(4), 297-310. doi:10.1016/j.hrmr.2010.10.005.

Prahalad, C. K., \& Hamel, G. (1990). The core competence of the corporation. Harvard Business Review, 68(3), 79-91.

Preacher, K. J., \& Hayes, A. F. (2008). Asymptotic and resampling strategies for assessing and comparing indirect effects in multiple mediator models. Behavior Research Methods, 40(3), 879-891. doi:10.3758/BRM.40.3.879.

Robbins, S. P., Judge, T. A., \& Sanghi, S. (2008). Organiation Behavior. India: Pearson education.

Seibert, S. E., Crant, M. J., \& Kraimer, M. L. (1999). Proactive personality and career success. Journal of Applied Psychology, 84(3), 416-427.

Seibert, S. E., Kraimer, M. L., \& Crant, J. M. (2001). What do proactive people do? Alongitudinal model linking proactive personality and career success. Personnel Psychology, 54(4), 845-874. doi:10.1111/j.1744-6570.2001. tb00234.x.

Senge, P. (1998). Sharing knowledge. Executive Excellence, 15, 11-12.

Sternberg, R. J., \& Lubart, T. I. (1999). The concept of creativity: Prospects and paradigms. In R. J. Sternberg (Ed.), Handbook of creativity (pp. 3-15). Cambridge: Cambridge University Press.

Szulanski, G. (1996). Exploring internal stickiness: Impediments to the transfer of best practice within the firm. Strategic Management Journal, 17(S2), 27-43. doi:10.1002/ smj.4250171105.

Teh, P. L., Yong, C. C., Chong, C. W., \& Yew, S. Y. (2011). Do the Big Five Personality Factors affect Knowledge Sharing Behavior? A study of Malaysian Universities. Malaysian Journal of Library and Information Science, 16(1), 47-62.

Tobin, R. M., Graziano, W. G., Vanman, E. J., \& Tassinary, L. G. (2000). Personality, emotional experience, and efforts to control emotions. Journal of Personality and Social Psychology, 79(4), 656-669. doi:10.1037/00223514.79.4.656.

Tierney, P., \& Farmer, S. M. (2002). Creative self-efficacy: Its potential antecedents and relationship to creative performance. Academy of Management Journal, 45(6), 1137-1148. doi:10.2307/3069429.

Thomas, K. M., \& Mathieu, J. E. (1994). Role of causal attributions in dynamic self- 


\section{Ekonomika a management}

regulation and goal processes. Journal of Applied Psychology, 79(6), 812-818. doi:10.1037/0021-9010.79.6.812.

Wah, L. (1999). Making knowledge stick. Management Review, 88(5), 24-29.

Watson, D., Clark, L. A., \& Tellegan, A. (1988). Development and validation of brief measures of positive and negative affect: The PANAS scales. Journal of Personality and Social Psychology, 54(6), 1063-1070. doi:10.1037/0022-3514.54.6.1063.

Wang, C., \& Yang, Y. (2007). Personality and intention to share k)owledge: an empirical study of scientists in an R\&D laboratory. Social Behavior and Personality, 35(10), 1427-1436. doi:10.2224/sbp.2007.35.10.1427.

Wang, S., Noe, R. A., \& Wang, Z. M. (2011). Motivating knowledge sharing in knowledge management systems: A quasi-field experiment. Journal of Management, 40(4), 978-1009. doi:10.1177/0149206311412192.

Webb, S. P. (1998). Knowledge management: Linchpin of change. London: The Association for Information Management (ASLIB).
Weiss, H. M., \& Cropanzano, R. (1996). Affective events theory: A theoretical discussion of the structure, causes and consequences of affective experiences at work. In B. M. Staw, \& L. L. Cummings (Eds.), Research in Organization Behavior: An Annual Series of Analytical Essays and Critical Reviews (Vol. 18, pp. 1-74).

Witt, L. A., Burker, L. A., Barrick, M. R., \& Mount, M. K. (2002). The interactive effects of conscientiousness and agreeableness on job performance. Journal of Applied Psychology, 87(1), 164-169. doi:10.1037/00219010.87.1.164.

Wu, Y. S. (2000). Knowledge Sharing in the Network Community (Master dissertation). Business Administration, National Cheng Chi University.

Wang, S., \& Noe, R. A. (2010). Knowledge sharing:A review and directions for future research. Human Resource Management Review, 20(2), 115-131. doi:10.1016/j.hrmr.2009.10.001.

Ch. Mahmood Anwar, M.S, EMBA, M.Sc. Scholars Index, USA MoST, Pakistan Mahmood.Anwar@scholarsindex.com 


\section{Abstract}

\section{LINKAGES BETWEEN PERSONALITY AND KNOWLEDGE SHARING BEHAVIOR IN WORKPLACE: MEDIATING ROLE OF AFFECTIVE STATES}

\section{Ch. Mahmood Anwar}

The purpose of this study was to investigate the relationship between broad and select narrow personality traits and knowledge sharing behavior of employees in workplace. This study especially contributes to literature of personality by uncovering the unexplored affective states in the context of knowledge sharing behavior. Sample was drawn by using simple random sampling without replacement technique. To test the hypotheses, correlation, regression and bootstrap mediation procedures were applied to the sample data. Testing a sample of 274 university teachers, significant associations were found between big five traits, proactive personality, creative self-efficacy, and knowledge sharing behavior. Openness to experience, conscientiousness, agreeableness, extraversion, proactive personality and creative self-efficacy were positively related to knowledge sharing behavior, whereas, neuroticism was negatively related to knowledge sharing behavior in workplace. The relationship between extraversion, agreeableness and creative self-efficacy was partially mediated by positive affect and the relationship between neuroticism and knowledge sharing behavior was partially mediated by negative affect. In conclusion, members of organizations, at all levels, should be trained to manage their emotions and affective reactions intelligently to share knowledge effectively and gain maximum benefits from knowledge based assets. In addition, organizational tasks must be assigned to employees with suitable narrow or broad personality traits to maximize the performance level. All the sophisticated, scientific and technical works requiring high level of knowledge sharing should not be assigned to neurotic workers. However, agreeable, extrovert, conscientious and open individuals may handle all knowledge sharing activities effectively. It is also suggested that the works requiring scientific innovation and creativity could better be performed by people high in creative self-efficacy, whereas, knowledge works requiring manual dexterity like technology transfer, industry academia linkages and knowledge based networking can best be done by proactive people.

Key Words: Broad and narrow personality traits, affective states, knowledge sharing behavior, Affective Events Theory, workplace behaviors.

JEL Classification: D83, M10.

DOI: 10.15240/tul/001/2017-2-008 